\title{
Ethnomedicinal application of species from genus Thymus in the Pirot County (Southeastern Serbia)
}

\author{
Marija Marković ${ }^{*}$, Dejan PljeVljakušić ${ }^{2}$, Biljana Nikolić ${ }^{3}$, LJUbinko Rakonjac ${ }^{3}$, AND \\ VESNA STANKOV JOVANOVIĆ ${ }^{1}$ \\ ${ }^{1}$ University of Niš, Faculty of Sciences and Mathematics, Višegradska 33, 18000 Niš, Republic of Serbia \\ ${ }^{2}$ Institute for Medicinal Plants Research "Dr. Josif Pančić", Belgrade, Tadeuša Košćuška 1, 11000 Belgrade, Republic of Serbia \\ ${ }^{3}$ Institute of Forestry, Belgrade, Kneza Višeslava 3, 11030 Belgrade, Republic of Serbia \\ *Corresponding author: marijam@pmf.ni.ac.rs
}

Received: August 10, 2020

Accepted: November 9, 2020

Published on-line: November 25, 2020

Published: December 25, 2020

\begin{abstract}
The species from genus Thymus are polymorphous plants from the family Lamiaceae, spread in Serbia in many species, subspecies, varieties, and forms. The aerial parts of species from genus Thymus have a long tradition of being used worldwide. The subject of this study was the research of ethnomedicinal application of thyme in Pirot County (Southeastern Serbia). Ethnomedicinal surveys were conducted among the population in four municipalities: Pirot, Babušnica, Bela Palanka, and Dimitrovgrad. It was noticed that $56.9 \%$ of interviewed persons use the species of genus Thymus in the Pirot County. They are usually used in the county's folk medicine in the form of herbal tea against colds to relieve dry and spastic cough, especially in bronchitis and asthma, and for sedation.
\end{abstract}

Key words: genus Thymus, ethnopharmacology, Pirot County

http://dx.doi.org/10.5937/leksir2040027M

\section{INTRODUCTION}

The species from genus Thymus are perennial herbs or semishrubs of the family Lamiaceae. In Serbia, they are highly polymorphous species, spread in 30 species, and many subspecies, varieties, and forms occurred differing in size, branching, and hairiness of the stems, the colors, the shape, the size of the hair of the leaves, and other morphological characteristics (Diklić, 1974; Jančić et al., 1995). The genus Thymus is very complex from the taxonomical and systematic point of view, demonstrating significant polymorphism in morphological characteristics and the composition of essential oils (Jarić et al., 2015a).

Thymus species have been used since ancient times to treat diseases of the respiratory and digestive systems (Zarzuelo and Crespo, 2002). In ancient Egypt, they were used to make perfumed balms for embalming and medical purposes, and in ancient Greece, according to Dioscorides, thyme was used to treat asthma and loosen congestion in the throat stomach (Jaric et al., 2015a). The pharmacological records of the Chilandar Medical Codex (15 ${ }^{\text {th }}$ and $16^{\text {th }}$ centuries) mention the use of thyme as a remedy against headaches caused by colds, laryngitis, and diseases of digestive organs and as an antitussive (Jarić et al., 2014).

The aerial part of species from genus Thymus have applications not only in folk medicine but also in modern medicine. It has antiseptic, fungicide, expectorant, spasmolytic, carmina- tive, sedative, diuretic, and diaphoretic activities (Aneva et al., 2018). Due to its pharmacological characteristics, the essential oil of species from genus Thymus represents an important natural resource for pharmaceutical industry, beside its antioxidnant and antimicrobial properties (Nikolić et al., 2019). Ilić et al. (2017) have evaluated the antibacterial and streptomycinmodifying activity of Thymus glabrescens essential oil, and its components geraniol, geranyl acetate, and thymol. In this study it was noticed that all substance-streptomycin combinations produced antagonistic interactions, and combinations between geraniol and thymol showed dominant additive effect. Species from genus Thymus are also the sources of natural products for nutritional supplements or functional food components in the dietary industry Jarić et al. (2015a); Nikolić et al. (2019)

In Pirot County (Southeastern Serbia), the species from genus Thymus are widespread at meadows and pastures, with collecting period May-September. The following compounds have been previously reported in Thymus spp.: geraniol, geranyl acetate and thymol as the main components of the essential oil, tannins, bitter substance, flavonoids (Marković et al., 2010) . A detailed review of aromatic plants presence in investigated and described plant communities on the Vidlič Mountain in the Pirot County was presented by Marković et al. (2019).

They have noticed the following species from the genus Thymus: Thymus striatus Vahl., Thymus glabrescens Willd., Thymus praecox Opiz subp. jankae (Čelak.) Jalas, Thymus pulegioides L. 
Table 1. The voucher specimens of plant taxa from genus Thymus in HMN herbarium, collected during the research in four municipalities of Pirot County

\begin{tabular}{|c|c|c|c|c|c|}
\hline Plant taxa & Synonim & Pirot & Babušnica & Bela Palanka & Dimitrovgrad \\
\hline Thymus longicaulis C. Presl. & Thymus moesiacus Velen. & - & - & - & 14381 \\
\hline $\begin{array}{l}\text { Thymus praecox Opiz. subsp. jankae } \\
\text { (Čelak) Jalas }\end{array}$ & Thymus jankae Čelak. & 14371 & - & 14379 & - \\
\hline $\begin{array}{l}\text { Thymus praecox Opiz. subsp } \\
\text { polytrichus (A. Kern. ex Borbas) }\end{array}$ & Thymus balcanus Borbás & 14372 & - & - & - \\
\hline $\begin{array}{l}\text { Thymus pulegioides L. subsp. } \\
\text { panonicus (All.) Kerguélen }\end{array}$ & Thymus pannonicus All. & 14373 & 14376 & 14380 & 14382 \\
\hline $\begin{array}{l}\text { Thymus pulegioides L. subsp. } \\
\text { pulegioides }\end{array}$ & Thymus pulegioides L. & 14374 & 14377 & - & - \\
\hline Thymus odoratissimus Mill. & Thymus glabrescens Willd. & 13263 & 14378 & - & 14230 \\
\hline Thymus striatus Vahl & Thymus comptus Friv. & 14375 & - & - & - \\
\hline
\end{tabular}

subsp. pulegioides, Thymus pulegioides L. subsp. montanum (Bentham) Ronniger, Thymus balcanus Borb., Thymus marschalianus Willd., Thymus pannonicus All. and Thymus moesiacus Velen. The aim of this study was to evaluate the knowledge of the local population of Pirot County about the plant species from genus Thymus, also known as "babina dušica", "dušičina", "majčina dušica," or "majkina dušica" to the local population of study area. This paper will discuss species' application from the genus Thymus based on a population survey in the studied area: Pirot, Babušnica, Bela Palanka, and Dimitrovgrad. Also, a comparison with other regions in Serbia was performed.

\section{METHODOLOGY}

The study area includes four municipalities Pirot, Bela Palanka, Babušnica, and Dimitrovgrad in Southeastern Serbia (Figure 1). It covers $2761 \mathrm{~km}^{2}$ (Pirot County GIS, 2019). The climate is temperate continental, with the transitional climatic variations to sub-mountain and mountain climate at altitude over 600 meters (Marković et al., 2010). Lists of medicinal plants in the Pirot County were recorded by Ranđelović et al. (1991), and Marković et al. (2010), while on the Vidlič Mountain in the study area were reported 60 aromatic plants were recorded by Marković et al. (2019; 2009).

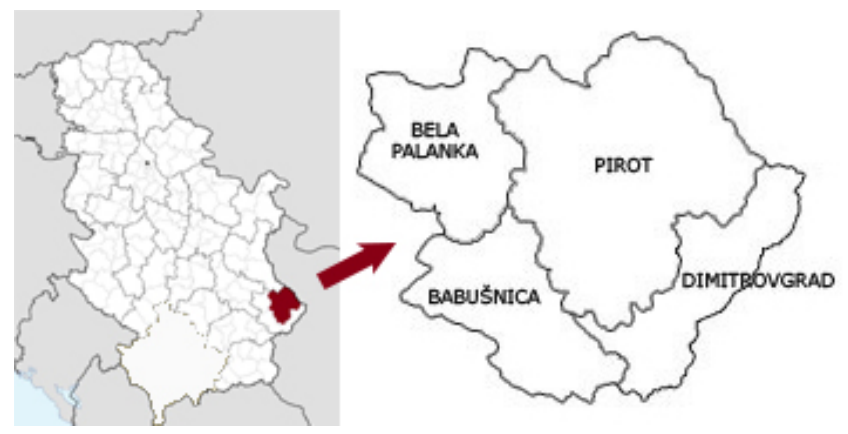

Fig. 1. Geographical position of Pirot County in Serbia and borders of four municipalities

Research about knowledge and use of medicinal plants in Pirot County was carried out during 2017, in the form of a population survey. The questionnaire about herbs' knowledge and use included inhabitants of 144 villages in the four municipalities. A total of 631 respondents were surveyed, of which 337 were male and 294 female (Marković et al., 2019; Stankov-Jovanović et al., 2018).

Information collected in the form of a questionnaire provided data about medicinal plants' knowledge among the local community at Pirot County. Data gathered from the participants were the common name of plants, the disease for which the plant is used, the plant part they use, and preparation forms. Special selection criteria were not carried out in the choice of the informants.

Plant species were identified according to Josifović (19701986), Jordanov (1963-1979), and Tutin et al. (1964-1980). The voucher specimens of collected plant material deposited in HMN herbarium are presented in Table 1. The nomenclature of the taxa listed, given at subspecies level, was compiled from database: The EURO+MED PlantBase - the information resource for Euro-Mediterranean plant diversity (Euro+Med, 2006-).

The results were systematized using Microsoft Excel and presented in Table 2 with the frequency of forms of application for traditional use, in Table 3 systematized regarding therapeutic groups with number of use reports per indication. Comparison with other regions in Serbia was also done using tabular overview (Table 4).

\section{RESULTS AND DISCUSSION}

\subsection{Quantitative analysis}

It was noticed that applications of species from genus Thymus (Thymus spp.) are well known among population of the Pirot County. A total of 359 of 631 interviewed persons i.e. $56.9 \%$ respondents mentioned "babina dušica", dušičina", "majčina dušica" or "majkina dućica" and their medicinal usage (Table 2,3), out of which 301 (83.85\%) of them were of Serbian nationality, 55 (15.32\%) were of Bulgarian nationality, and 3 $(0.83 \%)$ were Roma. Among respondents, a total of 180 were male, and 179 were female. In Pirot municipality, Thymus spp. were known to 198 (55.15\%) respondents, in municipality Babušnica 46 (12.81 \%), in municipality Bela Palanka 73 (20.34 \%) and municipality Dimitrovrgad 42 (11.70 \%) interviewed people. The age of respondents who mentioned Thymus spp. was from 16 to 85 . The majority of interviewed persons mentioned the use of the aerial part of the Thymus spp. in the form of tea in the treatment of common cold (149 persons, $41.50 \%$ ), cough (60 persons, $16.71 \%$ ), and for sedation (42 persons, $11.70 \%$ ). In the disease prevention, Thymus spp. were mentioned by 19 persons, and the same number of respondents were familiar with its application against stomach diseases, and eight respondents against lung diseases (asthma, bronchitis).

In the treatment of sore throat Thymus spp. was mentioned by seven persons, and the same number of people were familiar with their effect on stomach. 
Table 2. Forms of application in the traditional use of Thymus spp. in human ethnomedicine in Pirot County

\begin{tabular}{lrrrrr}
\hline Form of application & Pirot & Babušnica & Bela Palanka & Dimitrovgrad & Total \\
\hline Herbal tea & 195 & 46 & 71 & 42 & 354 \\
Alcoholic tincture & 1 & 0 & 1 & 0 & 2 \\
Dry herba & 1 & 0 & 1 & 0 & 2 \\
Oil extract & 1 & 0 & 0 & 0 & 1 \\
\hline
\end{tabular}

Table 3. Therapeutic groups and indications for traditional use of Thymus spp. in four municipitalities in the Pirot County

\begin{tabular}{|c|c|c|c|c|c|}
\hline Therapeutic group & Indication & Pirot & Babušnica & Bela Palanka & Dimitrovgrad \\
\hline \multirow[t]{6}{*}{ Respiratory } & Cold & 82 & 19 & 29 & 19 \\
\hline & Cough & 28 & 10 & 13 & 7 \\
\hline & Sore throat & 2 & 2 & 2 & 1 \\
\hline & Lung diseases & 5 & 1 & 1 & 1 \\
\hline & Bronchitis & 4 & - & 1 & - \\
\hline & Respiratory diseases (in general) & 2 & 2 & 1 & - \\
\hline \multirow[t]{5}{*}{ Nervous system } & Sedation & 28 & 4 & 6 & 4 \\
\hline & For nerves & 2 & - & - & 1 \\
\hline & Epilepsy & - & - & 1 & - \\
\hline & Filling the pillow against insomnia & 1 & - & - & - \\
\hline & For the good sleep & 1 & - & - & - \\
\hline \multirow[t]{2}{*}{ Digestive } & Stomach diseases & 10 & - & 6 & 3 \\
\hline & For stomach & 6 & - & 1 & - \\
\hline \multirow[t]{2}{*}{ Preventive } & Disease prevention (coffee replacement) & 11 & 3 & 3 & 2 \\
\hline & Improving the immune system & - & - & - & 2 \\
\hline Inflammation & Rinsing of the oral cavity & - & - & 1 & - \\
\hline \multirow[t]{2}{*}{ Cardiovascular } & For the heart & 2 & - & - & - \\
\hline & High blood pressure & 2 & - & - & - \\
\hline \multirow[t]{2}{*}{ Urogenital } & Kidney and bladder diseases & 2 & - & - & - \\
\hline & Menstrual pain & - & - & 1 & - \\
\hline \multirow[t]{8}{*}{ Various } & In the nutrition, as a spice & 1 & - & 4 & - \\
\hline & High temperature & 1 & 1 & 1 & - \\
\hline & Unknown use & 1 & 2 & - & - \\
\hline & Improving hearing & - & - & - & 2 \\
\hline & Headache & 2 & - & - & - \\
\hline & Antiseptic & - & - & 1 & - \\
\hline & Diabetes & 1 & - & - & - \\
\hline & Thyroid diseases & 1 & - & - & - \\
\hline
\end{tabular}

Five respondents mentioned application in nutrition as a spice. The same number of respondents were familiar with the usage of Thymus spp. in treating bronchitis and respiratory diseases (each one). The application for improving the immune system was mentioned by three respondents. The same number of persons was familiar with their effect against high temperature and the heart and nerves (sedative effects). Likewise, three people mentioned "majčina duišica" or "dušičina", but did not know its use. Two persons mentioned improving hearing, and the same number of respondents were familiar with its effect against headaches, against high blood pressure, and kidney and bladder diseases. One respondent mentioned usage of "majčina dušica" in the form of tea for rinsing the oral cavity, against thyroid diseases, one as an antibacterial antiseptic, for the treatment of influenza, against menstrual pain, against diabetes, against inflammation, and one was familiar with usage in the filling the pillow against insomnia and for good sleep.

The most common form of usage is the form of tea for oral application. Rarely used forms are extract, dry herba, and form of oil. Extract in alcohol is used against cough, dry herba in the nutrition as a spice, or for filling the pillow against insomnia. The form of oil is used for sedation.

\subsection{Comparative ethnopharmacological analysis}

The results of usage of species from genus Thymus of previous studies in neighboring regions in Serbia are presented in Table 4. 
Table 4. Overview of species from genus Thymus usage in neighboring regions of Serbia

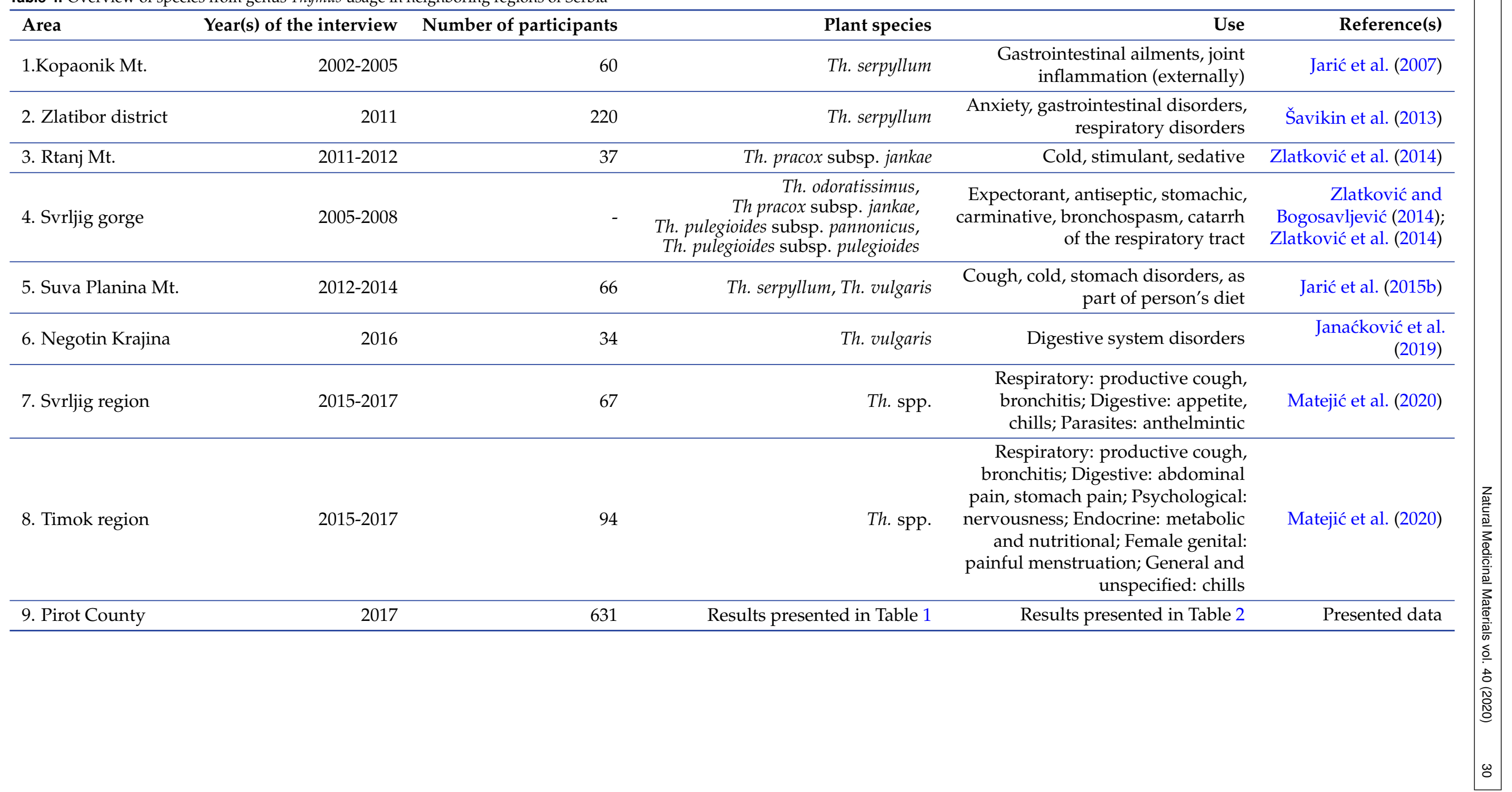


Furthermore, Matejić et al. (2020) were identified Thymus praecox Opiz for Timok and Svrljig region. However, they mentioned genus level (Thymus spp.) because there are other species from genus Thymus which may be used and have the same effect.

The present study results are in accordance with the findings of Zlatković and Bogosavljević (2014), Zlatković et al. (2014) and Matejić et al. (2020) probably as a result of proximity of investigated areas having in mind geographical locations of the geographical locations of the Svrljig, Timok, Rtanj Mountain, and Pirot County, which is probably caused by the proximity of these investigated areas. The following therapeutical applications of species from genus Thymus in the Pirot County systematized in therapeutic groups, are different and new from the above-mentioned ethnopharmacological studies in Serbia:

- Nervous system: epilepsy, filling the pillow against insomnia.

- Digestive system: for stomach.

- Inflammation: rinsing of the oral cavity, inflammation in general.

- Cardiovascular system: for the heart, high blood pressure.

- Urogenital system: kidney and bladder diseases.

- Various: headache, diabetes, improving hearing, thyroid diseases.

\section{CONCLUSION}

Based on the results of interviews with the local population in the Pirot conducted in this study, it can be concluded that species from genus Thymus commonly known as "babina dušica", "dušičina", majčina dušica", or "majkina dušica" are well known to people living in the rural areas, and they are used for indications from various therapeutic areas. The aerial part of Thymus spp. is frequently used in the form of tea for the treatment of cold, cough, and for sedation, and rarely in disease prevention, against stomach diseases, lung diseases, against sore throat, for the stomach, against respiratory diseases, improvement of the immune system, against high temperature, for the heart, for nerves, improving hearing, against headache, against high blood pressure, for rinsing the oral cavity, against thyroid diseases, as an antibacterial antiseptic, against epilepsy, against influenza, against menstrual pain, against inflammation, against diabetes. Except as tea, the species from genus Thymus are used as an extract against cough, dry herba is used in the nutrition as a spice or for filling the pillow against insomnia, and oil is used for sedation. During the research it was noticed the folowing plant taxa from genus Thymus: Thymus longicaulis C. Presl., Thymus praecox Opiz. subsp. jankae (Čelak) Jalas, Thymus praecox Opiz. subsp polytrichus (A. Kern. ex Borbas), Thymus pulegioides L. subsp. pannonicus (All.) Kerguélen, Thymus pulegioides L. subsp. pulegioides, Thymus odoratissimus Mill., and Thymus striatus Vahl. However, the respondents do not know the morphological differences between the observed different species from genus Thymus, represented in the Pirot County. They also do not mention the differences in their application. Some therapeutical applications of species from genus Thymus in the Pirot County are different and new in comparison with neighboring regions of Serbia, and that can be a starting point for new phytopharmacological investigations.

\section{ACKNOWLEDGMENTS}

This research is part of the project: Ethno-pharmacological study of the region of southeastern Serbia, O-02-17, supported by the Serbian Academy of Sciences and Arts.

\section{REFERENCES}

Aneva, I., Nikolova, M., Trendafilova, A. and Todorova, M. (2018). Composition of the essential oil of the Balkan endemic Thymus longedentatus (Degen \& Urum.) Ronniger, Facta Universitatis, Series Physics, Chemistry and Technology 16(1): 114.

Diklić, N. (1974). Rod Thymus 1., in M. Josifović (ed.), Flora SR Srbije, Vol. VI, Srpska Akademija Nauka i Umetnosti, Beograd, pp. 475-509.

Euro+Med (2006-). Euro+Med PlantBase - the information resource for Euro-Mediterranean plant diversity. Published on the Internet http:/ / ww2.bgbm.org/EuroPlusMed/ [23Sep-2020].

Ilić, B. S., Miladinović, D. L., Kocić, B. D., Spalović, B. R., Marković, M. S., Čolović, H. and Nikolić, D. M. (2017). Chemoinformatic investigation of antibiotic antagonism: The interference of Thymus glabrescens essential oil components with the action of Streptomycin, Natural Product Communications 12(10): 1934578X1701201.

Janaćković, P., Gavrilović, M., Savić, J., Marin, P. D. and Stevanović, Z. D. (2019). Traditional knowledge on plant use from Negotin Krajina (Eastern Serbia): An ethnobotanical study, Indian Journal of Traditional Knowledge 18(1): 25-33.

Jančić, R., Stošić, D., Mimica-Dukić, N. and Lakušić, B. (eds) (1995). Aromatične biljke Srbije, Dečje novine, Beograd, Gornji Milanovac.

Jarić, S., Mačukanović-Jocić, M., Đurđević, L., Mitrović, M., Kostić, O., Karadžić, B. and Pavlović, P. (2015b). An ethnobotanical survey of traditionally used plants on Suva Planina mountain (South-Eastern Serbia), Journal of Ethnopharmacology 175: 93-108.

Jarić, S., Mitrović, M., Karadžić, B., Kostić, O., Djurjević, L., Pavlović, M. and Pavlović, P. (2014). Plant resources used in Serbian medieval medicine. Ethnobotany and Ethnomedicine, Genetic Resources and Crop Evolution 61(7): 13591379.

Jarić, S., Mitrović, M. and Pavlović, P. (2015a). Review of Ethnobotanical, Phytochemical, and Pharmacological Study of Thymus serpyllum L., Evidence-Based Complementary and Alternative Medicine 2015: 1-10.

Jarić, S., Popović, Z., Mačukanović-Jocić, M., Djurdjević, L., Mijatović, M., Karadžić, B., Mitrović, M. and Pavlović, P. (2007). An ethnobotanical study on the usage of wild medicinal herbs from Kopaonik Mountain (Central Serbia), Journal of Ethnopharmacology 111(1): 160-175.

Jordanov, D. (ed.) (1963-1979). Flora Reipublicae Popularis Bulgaricae, Vol. 1-7, Aedibus Academiae Scientiarum Bulgaricae, Serdicae. [in Bulgarian].

Josifović, M. (ed.) (1970-1986). Flora SR Srbije, Vol. 1-9, Srpska Akademija Nauka i Umetnosti, Beograd. [in Serbian].

Marković, M., Matović, M., Pavlović, D., Zlatković, B., Marković, A., Jotić, B. and Stankov-Jovanović, V. (2010). Resources of medicinal plants and herbs collector's calendar of Pirot County (Serbia), Biologica Nyssana 1(1-2): 9-21. 
Marković, M., Matović, M. and Rakonjac, L. (2019). Review of aromatic plants of the Vidlič Mountain by phytocenological affiliation, Pirotski zbornik 44: 65-85.

Marković, M., Pavlović-Muratspahić, D., Matović, M., Marković, A. and Stankov-Jovanović, V. (2009). Aromatic flora of the Vidlič mountain, Biotechnology \& Biotechnological Equipment 23(2): 1225-1229.

Matejić, J. S., Stefanović, N., Ivković, M., Živanović, N., Marin, P. D. and Džamić, A. M. (2020). Traditional uses of autochthonous medicinal and ritual plants and other remedies for health in Eastern and South-Eastern Serbia, Journal of Ethnopharmacology 261: 113186.

Nikolić, B., Matović, M., Mladenović, K., Todosijević, M., Stanković, J., Đorđević, I., Marin, P. D. and Tešević, V. (2019) Volatiles of Thymus serpyllum obtained by three different methods, Natural Product Communications 14(6). Accepted: 2019-07-26T10:24:36Z.

Pirot County GIS (2019). Statistical office of the Republic of Serbia, register of spatial units and gis, administrative districts.

URL: www.stat.gov.rs

Ranđelović, N., Sotirov, S., Stamenković, V., Redžepi, F., Ranđelović, V. and Zlatković, B. (1991). Medicinal herbs of the Pirot subregion, Proceedings, Vol. 7/8, Faculty of Technology, Leskovac, pp. 29-33. [in Serbian].

Stankov-Jovanović, V., Šmelcerović, A., Smiljić, M., Ilić, M. and Marković, M. (2018). Ethnopharmacological application of St. John's wort in Pirot county, Pirotski zbornik 43(43): 141164.

Tutin, T., Heywood, V., Burges, N., Moore, D., Valentine, D., Walters, S. and Webb, D. (eds) (1964-1980). Flora Europaea, Vol. I-V, Cambrige University Press, London.

Šavikin, K., Zdunić, G., Menković, N., Živković, J., Ćujić, N., Tereščenko, M. and Bigovic, D. (2013). Ethnobotanical study on traditional use of medicinal plants in South-Western Serbia, Zlatibor district, Journal of Ethnopharmacology 146(3): 803810 .

Zarzuelo, A. and Crespo, E. (2002). The medicinal and non medicinal uses of thyme, in E. Stahl-Biskup and F. Saez (eds), Thyme, The genus Thymus: Medicinal and aromatic plants - industrial profiles,, Taylor and Francis, New York.

Zlatković, B. K. and Bogosavljević, S. (2014). Taxonomic and pharmacological valorization of the medicinal flora in Svrljiški Timok gorge (Eastern Serbia), Facta Universitatis, Series: Medicine and Biology 16(2): 76-86. Number: 2.

Zlatković, B. K., Bogosavljević, S. S., Radivojević, A. R. and Pavlović, M. A. (2014). Traditional use of the native medicinal plant resource of Mt. Rtanj (Eastern Serbia): ethnobotanical evaluation and comparison, Journal of Ethnopharmacology 151(1): 704-713. 